\title{
Дынаміка лахавіцкага маёнтку XVI ст.
}

Słowa kluczowe: majątek, Lachowicze, magnaci, Gasztołdowie

Keywords: manor, Liachavičy, tycoons, Haštoĺdy

\section{Development and formation Lyakhovichi manor in XVI ct.}

The article describes the history of development and formation Lyakhovichi manor in the period from the first mention in 1451 to the time of transfer of the ownership of the estate kind Chodkevich in 1572. The article also discusses the owners of Lyakhovichi manor. The attention paid to the formation of cultural and historical heritage of the city, as well as the processes associated with the release of the estates from the Lyakhovichi manor.

\section{Rozwój majątku Lachowicze w XVI wieku}

W artykule opisano historię rozwoju i kształtowania się majątku Lachowicze w okresie od pierwszej wzmianki o nim w 1451 roku do przeniesienia własności na ród Chodkiewiczów w 1572 roku. W artykule omówiono również historię rodu właścicieli majątku Lachowicze. Skupiono uwagę na rozwoju kulturowym i historycznym dziedzictwa miasta.

У пісьмовых крыніцах першыя звесткі, што датычаць Ляхавічаў з'яўляюцца ў XV ст. Яны вельмі лаканічныя i фрагментарныя. Так, у Літоўскай Метрыцы ад 14 верасня 1451 г. згадваецца дакумент аб наданні князем Аляксандрам (Алелькай) Уладзіміравічам 3 роду Гедымінавічаў Міцьку Іванавічу Гушчу двара Скеп’ева. Гэты дакумент «писал дьякъвоеводы виленского пана Ивана Кгаштолтовича Пенез. Писанълистьсес в Леховичохъ» ${ }^{1}$. Таксама ў дакуменце адзначана, што пры яго

\footnotetext{
${ }^{1}$ Литовская метрика 25. Книга записей (1387-1546), Вильнюс 1998, с. 460.
} 
напісанні, акрамя князя Алелькі і ваяводы Яна Гаштольда, у Ляхавічах прысутнічалі намеснік віцебскі Ян Гайцэвіч і падскрабі земскі Аляксандр Юр'евіч. Гэтыя звесткі даюць падставы меркаваць, што ў той час Ляхавічы былі важным месцам для сустрэч і вырашэння спраў літоўскай знаці. Аднак дакладна не вядома, каму належалі ў той час Ляхавічы.

Наступныя звесткі пра Ляхавічы перыяду XV ст. звязаны 3 недатаваным кароткім запісам зместу прывілея караля польскага і вялікага князя літоўскага Казіміра, аб наданні невядомаму ўладальніку Ляхавічаў права праводзіць тут кірмаш і трымаць корчмы². Зыходзячы з таго, што Казімір кіраваў дзяржавай з 1447 па 1492 гг., самай позняй датай выдачы прывілею можна лічыць 1492 г. Атрыманне права на кірмаш сведчыць, што Ляхавічы ў XV ст. былі не толькі аграрна-гандлёвым паселішчам - мястэчкам, але і адміністрацыйна-гаспадарчым цэнтрам буйной феадальнай вотчыны ${ }^{3}$.

3 перш. пал. XVI ст. Ляхавічы знаходзіліся ва ўласнасці Гаштольдаў. У гэты час, вядомы палітычны дзеяч Вялікага княства Літоўскага Альбрэхт Марцін Гаштольд, у выніку жаніцьбы 3 князёўнай С.В. Вярэйскай, якая з'яўлялася адзінай спадчынніцай шэрагу буйных маёнткаў, а таксама ў выніку куплі і велікакняжацкіх пажалаванняў становіцца ўласнікам вялікіх зямельных уладанняў. А. Гаштольд сканцэнтраваў у сваіх руках шэраг маёнткаў, якія знаходзіліся пераважна на Беларусі ${ }^{4}$. Ва ўладанні Гаштольда апынуліся і Ляхавічы з воласцю (дакладна не вядома, як менавіта гэты маёнтак апынуўся ў Гаштольда). Воласцю ў Вялікім княстве абазначалася ніжэйшай адміністрацыйная адзінка, а таксама тэрыторыя буйнога маёнтка. У той час

\footnotetext{
${ }^{2}$ Описание документов и бумаг, хранящиихя в Московском архиве Министерства юстиции, книга 21, Москва 1915, с. 414.

${ }^{3}$ Памяцьь: гісторыка-дакументальная хроніка Ляхавіцккага раёна, Мінск 1989, c. 29.

4 Там жа, с. 30
} 
Ляхавіцкага воласць складалася з замку і двара ў Ляхавічах, магчыма, некалькіх іншых двароў і вялікага ляснога абшару на правым беразе р. Шчара, які ў гістарычных крыніцах пазначаецца як пушча Лесішча 5 .

Стаўшы ўласнікам Ляхавіцкай воласці А.М. Гаштольд павялічваў межы свайго ўладання, набываючы новыя маёнткі, уключаючы іх у склад маёнтка Ляхавіцкага. Так, у траўні 1520 г. Гаштольд набыў у баярына навагрудскага Васка Паўліковіча двор Паўлюкоўшчына 6 . Затым, у 1525 г., набываецца маёнтак Брыкаўшчына і зямля на р. Ведзьма ${ }^{7}$ У 1532 Гаштольд купіў у пана Я.Ю. Ільініча двор Жарабковічы ${ }^{8}$.

Вядома, што ў 1535 г. на сродкі А.М. Гаштольда ў Ляхавічах быў узведзены першы касцёл. На яго ўтрыманне магнат выдзеліў двор Паўлюкоўшчыназ сялянамі ${ }^{9}$. Пазней (у 1554 г.) за касцёлам была замацавана мясная крама на рынку і хата-карчма без плацяжу адпаведных падаткаў ${ }^{10}$.

Ад Альбрэхта Гаштольда Ляхавічы ў складзе іншых маёнткаў пераходзяць яго сыну Станіславу Гаштольду. У 1537 г. Станіслаў Гаштольд 3 дазволу бацькі падарыў у якасці вена (матэрыяльнае забеспячэнне пасагу жонкі маёмасцю мужа) 8 тыс. коп грошай сваёй маладой жонцы Барбары Юр'еўне Радзівіл. А ў якасці залогу ёй былі перададзены Ляхавічы ${ }^{11}$. Станіслаў Гаштольд, які памёр у 1542 г.не пакінуўшы нашчадкаў, з'яўляўся апошнім прадстаўніком роду Гаштольдаў. Усе яго маёнткі як вымарачная

\footnotetext{
5 Литовская метрика 224. Книга записей (1522-1530), Вильнюс 1997, с. 187. ${ }^{6}$ Литовская метрика 10. Книга записей (1440-1523), Вильнюс 1997, с. 69.

${ }^{7}$ Описание документов и бумаг, хранящихся в Московском архиве..., ор.cit., c. 412 .

${ }^{8}$ Там жа, с. 405

${ }^{9}$ Нацыянальны гістарычны архіў Беларусь [далей: НГАБ], Ф. 1738. Воп. 1. Спр. 1. Л. 197.

${ }^{10}$ НГАБ Ф. 1738. Воп. 1. Спр. 1. Л. 196.

${ }^{11}$ Памяць: гісторыка-дакументальная..., ор.сіt, с. 32
} 
маёмасць (маёнтак, на які пасля смерці яго гаспадара ніхто не мог прад'явіць права па роднасці або паводле тастаменту; калі ўласнік не меў родных, маёмасць пераходзіла да Вялікага князя) перайшла князю Жыгімонту. Аднак Ляхавічы паводле дагавору 1537 г. павінны былі заставацца ва ўдавы Гаштольда да выплаты ёй 8 тыс. коп грошай ${ }^{12}$.

Далей склалася вельмі своеасаблівая сітуацыя, якая абумовіла знаходжанне Ляхавіцкай воласці ва ўласнасці Барбары Радзівіл да канца яе жыцця. У 1543 г. княгіня Радзівіл фактычна пабралася шлюбам з будучым вялікім князем Літоўскім Жыгімонтам II Аўгустам. Вянчанне ж адбылося ў 1547 г. калі Жыгімонт Аўгуст ужо ўзышоў на велікакняжацкі пасаг, а з 1548 г. - ён становіцца і каралём польскім.

У сувязі са шлюбам Барбары і Жыгімонта рада Вялікага княства Літоўскага ў 1548 г. для матэрыяльнага забеспячэння іх магчымых нашчадкаў мужчынскага полу, якія не будуць выбраны на велікакняжацкі трон, згадзілася перадаць Вялікаму князю ў якасці асабістай уласнасці маёнткі яго маці каралевы Боны, а таксама некаторых вымарачных маёнткаў у лік якіх уваходзілі і Ляхавічы ${ }^{13}$.

У часы уладання маёнткам княгіняй Радзівіл Ляхавічы ўяўлялі з сябе буйное гандлёвае мястэчка, дзе дзейнічаў каталіцкі касцёл і праваслаўная царква. Сведчаннем пра царкву 3'яўляецца факт нараджэння ў святара ляхавіцкай царквы Святога Юрыя айца Міхаіла Лявонавіча сына Фёдара ў $1546 \Gamma^{14}$. Сама ж воласць на момант перадачы яе Барбары Радзівіл дасягнула сваіх максімальных памераў, займаючы вялікія абшары.

Калі маёнтак Ляхавічы знаходзіўся ва ўласнасці Барбары Радзівіл, княжна перадавала пэўныя яго часткі ва ўласнасць іншым

\footnotetext{
12 Там жа.

13 Там жа.

14 У. Свяжынскі, «Гістарычныя запіскі» Фёдара Еўлашэўскага, Мінск 1990, c. 90 .
} 
панам. Так, частку маёнтка Ведзьма 3 вёскай Рамашкі атрымаў гаспадарскі зямянін В. Чаркоўскі, маёнтак Грушаўка перайшоў да шляхціца М. Залескага, зямля-урочышча Серкаўшчына была падараванай святару М. Лявонавічу. Пазней права на гэтыя маёнткі іх уладальнікаў было зацверджана вялікім князям і яны выйшлі са складу Ляхавіцкай воласці. Таксама ў часы Б. Радзівіл некаторыя маёнткі і фальваркі перадаваліся ў часовае ўладанне, як, напрыклад, сяло Еўлашэвічы ${ }^{15}$.

Пасля смерці Барбары Радзівіл у 1551 г. Ляхавічы і ўся воласць перайшла ва ўладанне яе мужа Жыгімонта Аўгуста ў якасці яго ўласнай маёмасці. У той жа час брат Барбары Радзівіл, які меў права на ляхавіцкі маёнтак саступіў яго вялікаму князю за 8 тыс. коп грошай. Так Ляхавічы трапілі ў склад буйных асабістых уладанняў Жыгімонта Аўгуста. Прыкладна да сяр. XVI ст. дакладнага падзелу гаспадарскіх уладанняў паміж уласнымі i дзяржаўныя не было, бо ўвесь даход 3 іх ішоў на ўтрыманне вялікага князя, яго двара, пакрыццё дзяржаўных расходаў. У той час Ляхавічы, як дзяржаўная маёмасць, называлася гаспадарскай ${ }^{16}$.

Як буйны землеўладальнік, Жыгімонт Аўгуст перадаваў у карыстанне іншым феадалам свае маёнткі. Перададзены ў арэнду маёнтак меў назву дзяржава, а той хто браў у арэнду - дзяржаўца. Першым ляхавіцкім дзяржаўцам быў у 1550-я г. падстараста слонімскі Рыгор Грынкевіч Валовіч ${ }^{17}$.

Наступным ляхавіцкім дзяржаўцай з'яўляўся Іван Аляксандравіч Солтан (двор знаходзіўся ў Жыровічах). 8 мая 1561 г. вялікі князь Жыгімонт Аўгуст пазычыў у І. Солтана 3 тыс. коп грошай, пакінуўшы пад залог Ляхавіцкую дзяржаву ${ }^{18}$.

\footnotetext{
${ }^{15}$ Памяцьь:гісторыка-дакументальная..., ор.cit., с. 71-76.

16 Там жа.

${ }^{17}$ Акты Виленской археографической комиссии: Том ХХІІ. Акты Слонимского земского суда,Вильна 1895, с. 41.

18 Чтения в Императорском Обществе Истории и Древностей Российских при Московском Университете. Выпуск 2, Москва1901, с. 624.
} 
У часы дзяржаўца Солтана ў Ляхавічах як і раней дзейнічае праваслаўная царква (5 верасня 1564 г. ляхавіцкі святар М. Лявонавіч атрымлівае дазвол ад князя Жылімонта Аўгуста на ўтрыманне ў сваім маёнтку карчмы ${ }^{19}$ ), знаходзіцца замак. 3 кнігі Актаў Слонімскага гарадскога суда вядома, што на Івана Солтана і яго падапечных неаднойчы скардзілася мясцовая шляхта. Так, 22 мая 1565 г. Солтан атрымаў прыпазоўны ад Л.М. Сідроўскага аб ...кгвалты, бои, грабежи и выбранье и пустопенье дерева, о увезанье без правное люди и отнятье кгрунту, о сажанье людей до везанья в замку Леховицкомъ... ${ }^{20}$.

Магчыма, у сувязі з гэтым, у 1566 г. Жыгімонт Аўгуст прыняў рашэнне перадаць Ляхавічы былому баярыну, уцекачу 3 Маскоўскай дзяржавы Уладзіміру Сямёнавічу Забалоцкаму і яго жонцы, ў пажыццёвае карыстанне 3 правам на 6 тыс. коп грошай. Пра матывы перабегу баярына ў Літву няма пэўных дадзеных (варта адзначыць, што ў той час ішла Лівонская вайна 1559-1583 гг.). Іван Жахлівы ў пасланні Курбскаму не ўзгадаваў Забалоцкага сярод сваіх “здраднікаў”. Маскоўскі цар прызнаваў, што «Володимер Заболочккой, розбранясь с своеюбратею, да бежал, а не от нашие опаль»» ${ }^{21}$. Прызначаючы дзяржаўцам В. Забалоцкага, князь кампенсаваў пазыку былому ўладару маёнтка I. Солтану. Перадача дзяржавы адбылася незадоўга да 1 ліпеня 1566 г. Але ва ўладанне дзяржавай Забалоцкі ўступіў толькі ў студзені 1567 г. (І. Солтан падаў скаргу ў суд на гаспадарскага двараніна C.M. Скробава, які уводзіў навага дзяржаўцу ва ўладанне маёнткам, бо той, па словах Солтана, падчас гэтай працэдуры прысвоіў яго маёмасць, якая захоўвалася ў адной з клецей Ляхавіцкага замку) $)^{22}$.

\footnotetext{
${ }^{19}$ Памящьь: гісторыка-дакументальная..., ор.cit., с. 62-63.

${ }^{20}$ Акты Виленской археографической комиссии: Том XXII..., ор.сіt., с. 240

${ }^{21}$ Описи изарского архива ХVI века и архива Посольского приказа 1614 г., Москва 1960 , c. 41.

22 Памяцьь: гісторыка-дакументальная..., ор.cit., с. 33.
} 
Перыяд кіравання ляхавіцкім маёнткам Забалоцкім характарызуецца супрацьстаяннем дзяржаўца 3 мясцовай шляхтай. У друг. пал. 1560-х гг. шляхта вымарачных маёнткаў актывізавала барацьбу за сваё раўнапраўе з павятовай шляхтай, што было звязана 3 інтэнсіўнымі працэсамі развіцця шляхецкай дэмакратыі ў ВКЛ (арганізацыя земскіх і гарадскі судоў, увядзенне Статуту 1566 г.). У гэтых умовах Ляхавіцкая васальная шляхта аднавіла сваю барацьбу, распачатую яшчэу 1551 г. беспаспяховай спробай дамагчыся пераходу пад “Земскае права” Навагрудскага павета. Так, на Гродзенскім сейме 1567 г. было абвешчана, што Забалоцкі парушае шляхецкія прывілеі, і шляхціцы звярнуліся з просьбай надаць ім статус шляхты Навагрудскага павета, а не Ляхавіцкага замка. На Гродзенскім сейме 1568 г. зноў падымалася пазначанае вышэй пытанне аб змене статусу шляхты, а таксама агучваліся скаргі на злачынствы і крыўды з боку дзяржаўца. На Люблінскім сойме ў лютым 1569 г. паслы зноў заявілі пра самавольства Забалоцкага і прасілі Жыгімонта Аўгуста дазволіць выкуп Ляхавіцкай дзяржавы. Дадзеная просьба каралём была адхіленая ${ }^{23}$.

У канцы 1569 г., у сувязі з жаданнем караля Жыгімонта Аўгуста абмяняць Ляхавічы на маёнтак Свіслач, які належаў пану Яну Гераніму Хадкевічу, Ляхавіцкая дзяржава была адабрана ў Забалоцкага. Дагавор Жыгімонта Аўгуста з Хадкевічам быў аформлены 10 красавіка 1572 г. у Варшаве падчас вальных сеймаў ${ }^{24}$.

За часамі, калі воласць знаходзілася ва ўладанні Жыгімонта Аўгуста тут назіраюцца тыя ж самыя працэсы, якія былі ў часы Барбары Радзівіл - перадача ва ўласнасць пэўных частак маёнтка іншым панам (не толькі ў васальнай залежнасці). Так, вялікі князь перадаў ва ўласнасць С. Гзоўскаму частку маёнтка Ведзьма 3 вёскамі ${ }^{25}$, маёнтак Начу - А. Брыдзу ${ }^{26}$. Пад юрысдыкцыю павета

${ }^{23}$ Там жа, с. 36.

24 Там жа, с.65.

${ }^{25}$ Там жа, с. 71.

${ }^{26}$ Литовская метрика 51. Книга записей (1566-1574), Вильнюс 2000, с. 8. 
выйшлі маёнтак Нача Атвілаўскае ${ }^{27}$ i ўласнасць шляхцічаў Нікіцічаў ${ }^{28}$.На момантперадачыдзяржавы ваўласнасць Хадкевічаў Ляхавічы ўяўлялі сабой досыць развітае гандлёвае мястэчка, дзе знаходзіўся драўляны замак, два храмы - праваслаўны і каталіцкі, дзейнічаў кірмаш, некалькі лавак, працавала карчма. У той жа час колькасць двароў і зямель, якія ўваходзілі ў склад маёнтка-ў параўнанні з 1550-мі гг. - скарацілася.

3 моманту перадачы Ляхавіцкай дзяржавы Хадкевічам пачынаецца новы этап развіцця гораду і маёнтка: Ляхавіцкая воласць набывае статус графства.

\section{Бібліяграфія:}

1. Акты Виленской археографическойкомиссии: Том ХХІІ. Акты Слонимского земского суда, Вильна, 1895.

2. Литовская метрика 10. Книга записей (1440-1523), Вильнюс 1997.

3. Литовская метрика 25. Книга записей (1387-1546), Вильнюс 1998.

4. Литовская метрика 51. Книга записей (1566-1574), Вильнюс 2000.

5. Литовская метрика 224. Книга записей (1522-1530), Вильнюс 1997.

6. Нацыянальны гістарычны архіў Беларусь, Ф. 1738. Воп. 1. Спр. 1.

7. Описание документов и бумаг, хранящихся в Московском архиве Министерства юстиции, книга 21, Москва 1915.

8. Описи царского архива ХVI века и архива Посольского приказа 1614 г., Москва 1960.

9. Памяць: гісторыка-дакументальная хроніка Ляхавіџкага раёна, Мінск 1989.

10. Рукописное отделение Виленской публичной библиотеки, Выпуск 1, Вильна 1871.

11. У. Свяжынскі, «Гістарычныя запіскі» Фёдара Еўлашэусккага, Мінск 1990.

12. Чтения в Императорском Обществе Истории и Древностей Российских при Московском Университете. Выпуск 2, Москва1901.

27 Там жа, с. 87.

${ }^{28}$ Рукописное отделение Виленской публичной библиотеки, Выпуск 1 , Вильна 1871, c. 78. 